\title{
Research ARticle: Relationship between socio-economic characteristics of IFS farmers and perception of usefulness of integrated farming system(IFS)
}

\section{Channamallikarjuna and A. T. Patil}

Article Chronicle : Received :

10.03.2019;

Revised :

09.04.2019;

Accepted :

10.05.2019

KEY WORDS:

Perception, Integrated farming system

Author for correspondence :

D. Channamallikarjuna

Department of

Agricultural Extension

Education, University of Agricultural Sciences,

Dharwad (Karnataka)

India

Email: channa.agri@

gmail.com

See end of the article for authors' affiliations
SUMMARY : The present study was conducted in Belagavi, Dharwad, Haveri and Uttar Kannada districts of northern Karnataka. The total sample size for the study was 160 integrated farming system (IFS) farmers. The Ex-post-facto research design was adopted for study. Findings of the study revealed that that nearly half of the IFS farmers belonged to middle age group, studied upto high school, IFS farmers belonged to low land holding, low income group. Majority of them belonged to medium experience category, material possession of the farmers was found to be medium with high economic motivation. Majority of the IFS farmers belonged to medium innovative proneness, risk orientation, mass media utilization, extension contact and training received belonged to low level. Majority of the farmers visited the nearest town once in fortnight. Among thirteen independent variables studied eight variables namely farming experience, material possession, economic motivation, innovative proneness, risk orientation, mass media utilization, extension contact and cosmopolitiness exhibited positive and significant relationship with perception of usefulness of IFS by farmers.

How to cite this article : Channamallikarjuna, D. and Patil, A. T. (2019). Relationship between socio-economic characteristics of IFS farmers and perception of usefulness of integrated farming system(IFS). Agric. Update, 14(2): 127-134; DOI : 10.15740/HAS/AU/14.2/127-134. Copyright@ 2019: Hind Agri-Horticultural Society. 